https://doi.org/10.24101/logos.2018.15

Gauta 20170914

YAN KAPRANOV

Kyiv National Linguistic University, Ukraine

Kijevo nacionalinis lingvistinis universitetas, Ukraina

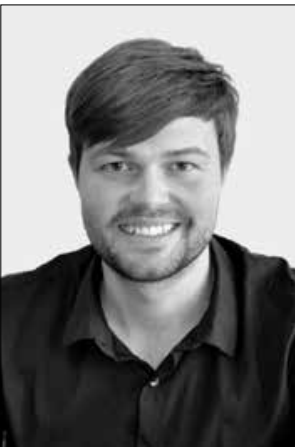

\title{
HIPOTETINÉS PIRMŲJŲ ŽMONIŲ POPULIACIJŲ ANTROPOGENINĖS LOKALIZACIJOS VERSIJOS
}

\author{
Hypothetical Versions \\ on Antropogenesis Localization \\ of the First Populations of the Homo
}

\begin{abstract}
SUMMARY
The article represents the views of scholars on the interpretation of the notions of the first taxons of the following Homo: Homo habilis, Homo rudolfensis, Homo erectus (ergaster). The refined definition of the "cradle of humankind" notion, i.e. the territory where one of the first representative of the Homo probably originated has been represented. The main anthropological and archaeological versions of localization of the first taxons of the Homo have been mentioned: radical change of diet and food strategy; improvement of locomotion based on the acquired bipedalism by hominids; the beginning of the systematic processing of stone, as well as the directed technological progress.
\end{abstract}

\section{SANTRAUKA}

Straipsnis pateikia mokslininkų pažiūras į homo habilis, homo rudolfensis ir homo erectus (ergaster), pirmųjų taksonų sąvokų interpretacijas; patikslintą „žmonijos lopšio" - teritorijos, kurioje galbūt atsirado pirmasis žmonijos atstovas - apibrěžimą. Taip pat jame minimos svarbiausios antropologinės ir archeologinės pirmųjų žmogaus taksonų lokalizacijos versijos: radikalios permainos maitinimosi strategijoje; hominidu igyto judèjimo ant dviejų kojų tobulejjimas; akmens apdirbimo ir nuolatinio panaudojimo pradžia bei nuosekli technologinė pažanga. 


\section{INTRODUCTION. SCIENTIFIC PROBLEM ON ANTHROPOGENESIS LOCALIZATION OF THE FIRST TAXONS OF THE HOMO}

The modern stage of science development is characterized by broad interdisciplinary approach, which enables to obtain more objective scientific results of the study, where complicated problems are represented. Up to now, one of the problems is the problem of anthropogenesis. Scholars from different branches of scientific knowledge try to study it. The main discussion deals with the focus on the localization of the representatives of the Homo, who have recently been predicted to exist on the African Continent (F. Grine, W. Jungers, J. Schultz, etc.).

The problem of the first representatives of the Homo, who were proposed to be called Homo habilis (habilis means "skilful, smart"1) by R. Dart, has not been fully understood yet. Subsequently, the full scientific notion of this representative of hominid has acquired more expanded form - Homo habilis Leakey, Tobias, Napier, 1964 - after the article "A new species of the genus Homo from Olduvai Gorge", written by L. Leakey, F. Tobias and J. Napier, was published. The scholars assumed that the Olduvai / Oldoway Gorge was not the only territory, where the Homo habilis settled, because the relicts of older hominids of such type were also found in Kenya and Ethiopia ${ }^{2}$.

\section{ANTHROPOLOGICAL AND PALEOANTHROPOLOGICAL VERSIONS ON THE FINDINGS OF THE RELICS OF THE FIRST POPULATIONS OF THE HOMO}

According to O. Zubov's hypothesis, a unique skull KNM-ER 1470 found by R. Leakey (the son of L. Leakey) in 1972 in the area of Koobi was one of the findings. It influenced the studies aimed at investigation of the origin and evolution of a human being ${ }^{3}$. R. Leakey, together with his colleagues J. Napier and F. Tobias, setting up 150 fragments of the skull, were impressed by the large size of the braincase of the Homo habilis $\left(775 \mathrm{~cm}^{3}\right)^{4}$. Later, after long-term studies, R. Leakey assumed that hominids of this type also originate from the Homo sapiens ${ }^{5}$.

Another problem was the establishment of an approximate dating of the skull KNM-ER 1470. The age of the find- ing was 2.9 million years ${ }^{6}$. According to O. Zubov's point of view, it required the greatly complicated study; therefore, later the dating was revised. Today the age of the finding is considered to be 1.89 million years ${ }^{7}$.

During excavations in the Ural Region, an incomplete lower jaw of a human being consisting of two parts was found in 1991. The results of the study were observed in the article "Paleoanthropology of the Malawi Rift: the early hominid mandible from the Chiwondo Beds, northern Malawi", written by T. Bromage, F. Schruck and F. Sonneveld, the paleoanthropologists ${ }^{8}$. The following conclusions were also made: taking into 
account the characteristics of the absolute sizes of molars (IO Ml - $15.1 \mathrm{~mm}$; VL Ml - 12.8 mm; MOE M2 - 18.3 mm (!); VL M2 - $14.2 \mathrm{~mm}$ ) and premolars (the first premolar - $\mathrm{MO}-0,2 \mathrm{~mm}$; VL $12.3 \mathrm{~mm}$; the second - $\mathrm{MO}-10 ; 4 \mathrm{~mm}$, $\mathrm{VL}-11.8 \mathrm{~mm}$.), crown indexes, area of humps, etc. the finding could be the early Homo. Although it is possible to mention "individual sizes do not go beyond the variations of the teeth of the Australopithecus"' . It enabled the scholars to admit the existence of another taxonomic type of the Homo - Homo rudolfensis, the hypothetical age of which could be between 2.5 and 2.3 million years. The paleoanthropologists assumed that this taxon originated in the East Africa 2.5 million years ago, because of the cold climate. This is the reason why it was considered to be endemic. Probably, a common ancestor of the Homo rudolfensis and Australopithecuses (A. afarensis or A. aethiopicus) had been there by this time ${ }^{10}$.

In 1996, comparing the skull KNM-ER 1470 and the lower jaw UR 501, F. Fitch, J. Miller, J. Mitchell, the British scholars, having received new important data, proposed the following assumption: "The finding of the Homo rudolfensis is "younger" for 3,31 million years, it is "younger" for 2,5 million years, but "older" for 1,9 million years, which allows the above-mentioned skull to be supposed as one of the oldest in Africa and in the world." It means that this skull refers to the forms that may be considered to be the "first" people on Earth"

Another fragment of the skull, found in 1965, is worth mentioning. According to O. Zubov's point of view, it has been "raising doubts and controversies for a long period of time" and today it "attracts attention again as a possible hypothesis of the existence of the most ancient representatives of the Homo in Africa two million years ago"12. This is the finding KNM-BC 1, or "Chemeron temporal", i.e. a temporal bone from Baringo (the formation of Chameron, the Tugen Hills, Kenya), whose approximate age, according to R. Sherwood, S. Ward and A. Hill observations, is equal to 2,456 $\pm 0,006$ and $2,393 \pm 0,013$ million years (calculations made with the help of two methods: $\left.{ }^{40} \mathrm{AR} /{ }^{39} \mathrm{AR}\right){ }^{13}$. P. Tobias was one of the first scholars who began to study this relict. Having represented a difficult diagnosis of some signs of this copy, he gave it a hypothetical previous name Hominidae, gen. et sp. indet. ${ }^{14}$. After his studies, A. Hill proposed a version for including the "temporal bone from Chemeron" to the Homo ${ }^{15}$, but B. Wood generally assumed that the finding might have referred to the Homo rudolfensis ${ }^{16}$.

According to the point of view of S. Prat, J.-P. Brugal, J.-J. Tiersellin, J.-J. Barrat et al., there was one more relict, found in 2002 in the west of Lake Turkana (the Nachukui formation). It was the first lower molar (at the stage of eruption) of a child aged 4-5 years that is "perfectly preserved". The approximate age of it is 2.3-2.4 million years. Taxonomically, it can probably also be included to the $\mathrm{Homo}^{17}$. The scholars note that this lower constant child molar KNM-WT 42718 has all the features of the first molar (taking into account the era): relatively small crown sizes, especially the vestibule-lingual diameter (MD - $13.7 \mathrm{~mm}$, VL $11.6 \mathrm{~mm}$, width of trigonometry - 
$11.3 \mathrm{~mm}$, talonid - $11.6 \mathrm{~mm}$ ), incomplete complex of morphological differentiation of crowns, etc. S. Prat, together with his colleagues, assumed that the general morphology, especially the moderate reduction of the crown and the small vestibulelingual diameter, probably distinguishes the found molar from the same names of Australopithecuses (A. afarensis, A. anamensis, africanus) and it helps to include the relicts to the Homo ${ }^{18}$.

The next relict (a well-preserved upper jaw A.L. $666-1$ of a human being) was found in November 1994 on a littlestudied area of Ethiopia. The hypothetical age of it (2.33 \pm 0.07 million years) was successfully reconstructed with the help of two methods ${ }^{40} \mathrm{AR}$ and ${ }^{39} \mathrm{AR}$. According to the hypothesis of W. Kimbel, R. Walter, D. Johanson et al., it "put the above-mentioned copy in line with the oldest relicts of the first representatives of the Homo," because "its special value means the oldest well-dated copy of the Homo, found together with the stone tools"19. In addition, scholars also assume that the diamond-shaped form is likely to indicate similarity to the early Homo ergaster, but they point to the topical molars of the Homo habilis and Homo rudolfensis that have the same form ${ }^{20}$. O. Zubov argues that modern human beings occasionally have the same upper molar and it refers to the Neanderthals ${ }^{21}$.

At the same time, W. Kimbel, together with his colleagues, carried out a comparative analysis of the copy A.L. 666-1 and the oldest skeletal fragments of the Homo, which is $\mathrm{OH} 16, \mathrm{OH} 39$, to determine the taxonomic status of A.L. 666-1. It gave them the opportunity to formulate the hypothesis that A.L. $666-1$ is probably the closest to the Homo habilis sensu stricto ${ }^{22}$. O. Zubov calls this version interesting, because, in his words, it "demonstrates the probability of revealing a generalized version of the first human being" 23 .

There is also a version, given by D. Johanson and B. Blake, that the representative of the Homo rudolfensis (2.4-1.9 million years) and Homo habilis (lived 1.91.6 million years ago) are considered to be the most ancient species ${ }^{24}$. Of course, today there is still the following discussion: which of these two species could be the ancestor of the modern human being of the Homo sapiens. However, according to O. Zubov's assumption, it we speak about the relicts found in Ethiopia, the Homo habilis sensu stricto is not the old one of the type among the Homo, than the Homo rudolfensis ${ }^{25}$.

\section{VERSIONS ON TIME OF ORIGIN, RANGE OF RESETTLEMENT AND REASONS FOR SURVIVAL OF THE FIRST HUMAN POPULATIONS (CRADLE OF HUMANKIND)}

One way or another, the conducted anthropological and archaeological studies of the late XX - early XXI century allowed many scholars (B. Blake, D. Johanson, D. Johansson, W. Kimbel, R. Walter, etc.) to formulate a version of the probable place and time of origin and existence of the first human populations. Their settlement was limited to the lands that now are a part of Kenya, Ethiopia and 
Tanzania. The scholars of different branches of scientific knowledge agree that this territory can be hypothetically called "Cradle of Humankind" (Rus. "колыбель человечества"), where, most probably, the first representatives of the Homo originated. It is the period approximately from 2.4 to 2.0 million years ${ }^{26}$.

According to A. Isbell's and T. Young's version, the period of the "cradle" in the period of evolution of a human being falls at the time of significant climatelandscape changes in Eastern Africa, as well as the general, global environmental changes that began in the Miocene ${ }^{27}$. At the same time, R. Bobe, A. Behrensmeyer, R. Chapman assume that the main trend of these changes were the deviation of the forests and the formation of dry open spaces between 3.4 and 2.0 million years and up to now ${ }^{28}$, but the "acute phase of aridity" probably came 2.5 million years ago, which was coincided with such major events in anthropogenesis as the origin of the Homo and the beginning of the Stone Age in technology ${ }^{29}$. K. Reed admits that the occurrence of the old hominids by new important adaptations to the environment is associated with the release of savannas, as well as the ecological changes are likely to contribute to the extinction of many groups of hominids. That is why, the Homo in this family was the first taxon, which, according to K. Reed's point of view, "managed to adapt to the open arid spaces" ${ }^{\prime 30}$.

The scholars (T. Bromage, F. Schrenck and F. Zonneveld) argue for a version that initially a species arose (a primary population), within which there were routine processes of a certain differen- tiation $^{31}$. According to their opinion, it could have been the Homo rudolfensis. However, if we were to pay attention to the above-mentioned findings in Kada Hadar, one could have dwell on a more general definition of the Proto population of a human being, i.e. Homo habilis sensu lato ${ }^{32}$.

O. Zubov assumed the responsibility and said that it does not matter whether it was the Homo rudolfensis, or Homo habilis (or Homo habilis sensu lato / Homo habilis sensu stricto), but their further evolution is closely connected with the processes of adaptation to the changes of the natural conditions of this region; their physical state and behavior reflect the struggle for survival in the Plio-Pleistocene African "cradle"33.

According to A. Turner's version, the evolutionary biologists consider the origin of the Homo as a general phenomenon for a large-scale coup in the mammals' fauna. Perhaps, it happened because of climatic changes in the average Pliocene, culminating 2.5 million years ago. Moreover, the scholar represents his hypothesis because later tectonic and climatic factors continued to play a leading role in the formation of the physical and biotic environment of the region ${ }^{34}$.

Based on the above-mentioned hypotheses on the origin of a probable taxon of the Homo, O. Zubov formulates three extremely important versions that could have played a leading role in its formation, as well as its further evolution, both in the process of adaptation in the eastern regions of Africa and due to the formation of a new generation of hominids. The following three versions proposed: the first version deals with a 
radical change in diets and food strategy; the second one - the improvement of locomotion based on the acquired hominid of bipedalism family; the third one the beginning of the systematic processing of stone and technological progress $\mathrm{s}^{35}$.

These hypotheses have identified the success of the Homo in the struggle for survival $^{36}$. The scholar M. Butovskaya also assumes that the deforestation and depletion of plant food sources probably contributed to the transition of hominids to plant products, because the early Homo before the occurrence of Homo ergaster had not been hunters yet and a large wild fowl was inaccessible to them ${ }^{37}$.

\section{FOOD AND BEHAVIORAL STRATEGIES FOR SURVIVAL OF THE FIRST TAXONS OF THE HOMO}

Hypothetically, R. Dennell characterizes the food strategy of the first people, calling them the population of scavengers, i.e. the "creatures that eat low-fat food," because it does not correspond to the dead animals, but to the tactics of "eating up" of the wild fowl after large predators. The scholar represented his own view of the evolution of their food process: if in the early stages of the evolution of the Homo this form of primary transition to animal food was mostly the form of passive scavengers, then the already urgent necessity for protein food, the gained experience, the improvement of guns and the increasing level of organization of groups allowed the hominids to rise to a new, higher degree of food strategy - a confrontational (aggressive) scavengers form ${ }^{38}$, in which rushing might seriously compete with other "contenders" for access to carcasses and probably they were able to fight for food with the predators ${ }^{39}$.

Due to this behavior of the Homo, the following question is raised: what place they occupied in the system of relationships between taxons of African mammals and, first of all, predators, with which a human being developed constant forced contacts after the transition of the oldest Homo to food of plant origin $^{40}$. According to M. DominguezRodrigo's version, due to the low overall level of interspecies competition in the savanna and therefore the hominids had relatively safe access to carcasses, the overall situation was quite favorable in many cases for the early Homo in the Plio-Pleistocene of Africa ${ }^{41}$. M. Lewis complements the assumption of his colleague and argue that this could be facilitated by the extinction of a number of large predators, which began about 2 million years $\mathrm{ago}^{42}$.

In the anthropological literature, there are still lively discussions about whether the first people whether large predators hunted them. The scholars try to be guided not only by the facts of the attack on animals, but by systematic hunting where a human being could have become a constant prey for a leopard or a lion ${ }^{43}$. D. Hart and R. Sussman, the English anthropologists' tend to respond positively to the posed issue in the article "Man the Hunted: Primates, Predators, and Human Evolution" $^{44}$. K. Ward, the American re- 
searcher-anthropologist, disagrees with this and provides very important arguments. Above all, he points to the fact that the found relicts of the mixed bones of Plio-Pleistocene predators are observed in the bones of the baboons and massive Australopithecuses, but there are no bones of the $\mathrm{Homo}^{45}$.

\section{IMPROVEMENT OF LOCOMOTION BASED ON ACQUIRED BIPEDALISM BY HOMINID FAMILY}

According to O. Zubov's probabilistic prediction, taking into account the conditions of significant changes in the environment the survival was in need of the morphophysiological rearrangements of the body of the early Homo. In this case, the struggle for high-calorie foods became a vital factor in the existence of these hominids ${ }^{46}$. Rodman and McHenry state that "the large distances between unpredictable sources of food, primarily due to the displacement of large predators and their wild fowl, contributed to the formation of new locomotor devices in hominids - to overcome quickly large distances based on inherited bipedal ancestors that provided advantages in speed and energy efficiency".

According to the assumption of D. Bramble and D. Liberman, the American anthropologists, two-legged locomo- tion could include two modes of movement - walking and running, among which "there are not only quantitative but also qualitative biomechanical differences $^{\prime \prime 4}$. The development of running skills has become one of the most important factors for the survival and further human evolution in Plio-Pleistocene ${ }^{48}$. "The value of running as an aromatic property of the Homo was determined not only and not even so much by the following speed advantages: getting stamina, overcoming significant distances in open spaces" (endurance running - ER the term of D. Bramble and D. Liberman $)^{49}$. It was unique among primates ( 2 million years) and helped to identify the adaptation to changes of natural conditions of the "cradle" of the Homo, which has reached perfection in populations of the Homo erectus (ergaster) ${ }^{50}$.

\section{BEGINNING OF SYSTEMATIC STONE PROCESSING AND TECHNOLOGICAL PROGRESS}

Another feature of the Homo was the acquiring the skills in the stone use and processing. Almost simultaneously, when the human race started to exist the Stone Age began and the first technologies were discovered, the time of establishing the approximate date of its occurrence has certain difficulties ${ }^{51}$. According to the point of view of S. Semaw, M. Rogers et al., the cannon criterion of the Homo gives a certain amount of space to make the populations more ancient: excavations in Kada Gona (Ethiopia) have shown that some hominids were able to make stone tools already 2.6 million years ago and even 2.9 million years later ${ }^{52}$. 
In general, stone tools processing played an important role in anthropogenesis as one of the forms of complex behavior, which was a "parallel" line of development along with the main direction of the aromatic, main evolution of the first populations of the Homo. A human being is assumed to have begun to process the stone, because of a highly developed brain. Therefore, from the biological point of view, a human being was not a highly specialized creature throughout the period of its existence and a special form of its evolution facilitated it. It allowed maintaining the morphophysiological "neutrality" to some extent, in which the stone industry played a significant role. Thanks to the technology, some of the hominids had acquired the ability to turn their habitat more or less into one another ${ }^{53}$.

A number of significant evolutionary progressive shifts, which reflect the continuous process of speciation, culminating in the formation of the Homo erectus (ergaster), characterizes the period of the biological history of a human being. It means that the development of a new type of locomotion, the corresponding change in body proportions (elongation of the lower extremities), increase in body size, improvement of bipedalism were partly connected with the thermoregulatory processes in the process of development of an open seaman ${ }^{54}$.

A. Turner assumes that "tectonic and climatic changes continued to play a leading role in shaping the physical and biotic environment of the region" ${ }^{55}$. At the same time, O. Zubov draws attention to one exception - the major increase and improvement of the brain. It is difficult to explain the direct effect of climate change, nevertheless almost any complicated system has a certain aromatic component. But due to such high level of development, which is special for hominids, an increasingly important role refers not only to the influence of external factors, but to the active interaction of creatures with these conditions and, above all, to the interaction with the surrounding animal world ${ }^{56}$. R. Foley, the English anthropologist, wrote the following in one of his works of the 90s: "the mechanism of climate impact on evolution is traced through extinction and other factors that depend on local conditions of competition playing a more significant role in the emergence of new taxons" 57 .

\section{CONCLUSIONS}

Summing up the analysis of various hypotheses on the anthropogenesis represented in the article, it should be noted that based on the archaeological finding of various relicts of the Homo, scholars assume the existence of the following populations: Homo habilis, Homo rudolfensis, Homo erectus (ergaster). The following factors played a significant role in the evolution: radical change of diet and food strategy; improvement of locomotion by hominid family based on acquired bipedalism; the beginning of the systematic stone processing, as well as the directed technological progress at that period time. 


\section{Literature and References}

1 Зубов А. А. 2011. Становление и первоначальное расселение рода Ното. СПб.: Алетейя. с. 16.

2 Leakey L. S. 1964. A New Species of The Genus Homo From Olduvai Gorge. B.: Nature. Vol. 202. Issue 4927. p. 7-9.

3 Зубов А. А. 2011, с. 16.

4 Leakey L. S., p. 7-9.

5 Ibid.

6 Ibid.

7 Зубов А. А. 2011, с. 17.

8 Bromage T. O., Schrenk F., Zonneveld F. 1995. Paleoanthropology of the Malawi Rift: an early hominid mandible from the Chiwondo Beds, northern Malawi // J. Hum. Evol. Vol. 28. p. 71-108.

9 Ibid.

10 Ibid.

11 Fitch F. J., Miller J. A., Mitchell J. O. 1996. Dating of the KBS Tuff and Homo rudolfensis // J. Hum. Evol. Vol. 30. p. 277-286.

12 Зубов А. А. 2011, с. 18.

13 Sherwood R., Ward S.C., Hill A. 2002. The taxonomic status of the Chemeron temporal (KNM-BC 1) // J. Hum. Evol. Vol. 42. p. 153-184.

14 Tobias P. V. 1991. The skulls, endocasts and teeth of Homo habilis // Olduvai Gorge. Cambridge. Vol. 4. p. 1-921.

15 Sherwood R., Ward S.C., Hill A. 2002, p. 153184.

16 Wood B. 1992. Origin and evolution of the genus Homo // Nature. Vol. 355. p. 783-790.

17 Prat S., Brugal I.-Ph., Tiercelin J.-J., Barrat J.-J., Bohn M., Delagues A., Harmand S., Kimeu K., Kibunjia M., Texier P.-S., Roch H. 2005. First occurrence of early Homo in the Nachukui Formation (West Turkana, Kenya) at 2.3-2.4 Myr // J. Hum. Evol. Vol. 49. p. 230-240.

18 Prat S., Brugal I.-Ph. et al. 2005, p. 235.

19 Kimbel W. H., Walter R. C., Johanson D. C., Reed K. E., Aronson J. L., Assefa Z., Marean C. W., Eck G. G., Bobe R., Howers E., Rak Y., Vondra C., Yemane N., York D., Chen Y., Evensen N. M., Smith P. E. 1996. Late Pliocene Homo and Oldowan tools from the Hadar formation (Kada Hadar member), Ethiopia // J. Hum. Eyo1. Vol. 31. p. 549-561.

20 Ibid.

21 Зубов А. А., Халдеева Н. Н. 1989. Одонтология в современной антропологии. М.: Наука. 232 c.
${ }^{22}$ Kimbel W. H., Walter R. C. et al. 1996, p. 549561.

23 Зубов А. А. 2011, с. 20.

24 Johanson D., Blake B. 1996. From Lucy to language. London.

25 Зубов А. А. 2011, с. 20.

26 Зубов А. А. 2011, с. 22.

27 Isbell I. A., Young T. P. 1996. The evo1ution of bipedalism in hominids and reduced group size in chimpanzees: alternative responses to decreasing resource availability // J. Hum. Evol. Vo1. 30. p. 389-397.

28 Bobe R., Behrensmeyer A. K., Chapman R. E. 2002. Faunal change, environmental variability and late Pliocene hominin evolution // J. Hum. Evol. Vol. 42. p. 475-497.

29 Hill A. 1994. Early hominid behaviora1 ecology: a personal postscript // J. Hum. Evol. Vo1. 27. P. 321-332.

30 Reed K. E. 1997. Early hominid evolution and ecologica1 change through the African Plio-Pleistocene // J. Hum. Evol. Vol. 32. p. 289-322.

31 Bromage T. O., Schrenk F., Zonneveld F. 1995, p. 71-108.

32 Зубов А. А. 2011, с. 22.

33 Зубов А. А. 2011, с. 22-23.

34 Тернер А. 1997. Распространение ранних гоминид // Человек заселяет планету Земля. Глобальное расселение гоминид. М. с. 7-21.

35 Зубов А. А. 2011, с. 23.

36 Зубов А. А. 2011, с. 23.

37 Бутовская М. А. 1997. Социальная структура ранних гоминид и проблема адаптациии к различным климатическим условиям в палеолиmе // Человек заселяет планету Земля. Глобальное расселение гоминид. М. с. 21-28.

38 Dennell R. 2003. Dispersal and colonization, long and short chronologies: how continuous is the Early Pleistocene record for hominids outside East Africa? // J. Hum. Evol. Vol. 45. p. 421-440.

39 Treves A., Naughton-Treves L. 1999. Risk and opportunity for humans coexisting with large carnivores // J. Hum. Evol. Vol. 36. p. 275-282.

40 Зубов А. А. 2011, с. 25.

41 Dominguez-Rodrigo M. 2001. A study of carnivore competition in riparian and open habitats of modern savannas and its implications for hominid behavioral modelling // J. Hum. Evol. Vol. 40. p. 77-98. 
42 Lewis M. E. 1997. Carnivoran paleoguilds of Africa: implications for hominid food procurement strategies // J. Hum. Evol. Vol. 32. p. 257-288.

43 Зубов А. А. 2011, с. 25.

${ }^{44}$ Ward C. V. (book reviews). 2005. Vol. 49. p. 777780. Hart O. \& Sussman R. W. 2005. Man the Hunted: Primates. Predators and Human Evolution.

45 Ibid.

46 Зубов А. А. 2011, с. 25.

47 Bramble D. M., Lieberman D. E. 2004. Endurance running and the evolution of Homo // Nature. Vol. 432. No. 18. p. 345-350.

48 Зубов А. А. 2011, с. 26.

49 Bramble D. M., Lieberman D. E. 2004, p. 345-350.

${ }^{50}$ Isbell I. A., Young T. P. 1996, p. 389-397.

51 Зубов А. А. 2011, с. 26.
52 Semaw S., Rogers M. J., Quade J., Renne P. R., Butler R. P., Dominguez-Rodrigo M., Stout D., Hart W. S., Pickering T., Simpson S. W. 2003. 2,6-million-year-old stone tools fined associated bones for OGS-6 and OGS-7, Gona, Afar, Ethiopia // J. Hum. Evol. Vol. 45. p. 169-177.

53 Тернер А. 1997, с. 7-21.

54 Amaral L. Q. 1996. Loss of body hair, bipedality and thermoregulation. Comments on recent papers in the Journal of Human Evolution // J. Hum. Evol. Vol. 30. p. 357-366.

55 Тернер А. 1997, с. 7-21.

56 Зубов А. А. 2011, с. 30.

57 Foley R. A. 1994. Speciation, extinction and climatic change in hominid evolution // J. Hum. Evol. Vol. 26. p. 275-289. 